\title{
Model Pembiayaan Infrastruktur Melalui Perusahaan Dana Pensiun Dengan Instrumen Sukuk Yang Diterbitkan Oleh Perusahaan BUMN
}

\author{
Rahmayati Nasution \\ Fakultas Agama Islam, UMSU \\ Jl. Kapten Muchtar Basri No. 3 Medan 20221 \\ email: Rahmayati143@yahoo.co.id
}

\begin{abstract}
ABSTRAK
Penelitian ini bertujuan untuk menawarkan model dalam hal pengembangan infrastruktur di Indonesia melalui penerbitan Sukuk yang disesuaikan berdasarkan tujuan penggunaan dan jenis infrastrukturnya, yaitu dengan akad Musyarakah Muqtanaqishah (MMQ), Ijarah, Mudharabah, Murabahah, dan Isthisna oleh perusahaan BUMN kemudian menawarkan Sukuk tersebut kepada perusahaan dana pensiun. Metodologi dalam penelitian ini menggunakan pendekatan berfikir sistem dengan teknik pengumpulan data sekunder yang diperoleh dari literatur yang mendukung. Hasil dari penelitian ini bahwa industri keuangan non bank di Indonesia perannya sangat penting bagi perkembangan infrastruktur yaitu dengan media dana pensiun dimana instrumennya adalah Sukuk yaitu dengan menggunakan akad musyarakah dan Musyarakah Muqtanaqishah (MMQ).
\end{abstract}

Kata Kunci: Sukuk, Musyarakah Muqtanaqishah (MMQ), Perusahaan Dana Pensiun, Infrastruktur. 


\title{
Infrastructure Financing Model Through Pension Fund Company With Sukuk Instrument Published By State Enterprise
}

\begin{abstract}
This study aims to offer a model in terms of infrastructure development in Indonesia through the issuance of sukuk which is adjusted based on the purpose of use and the type of infrastructure, namely Musyarakah Muqtanaqishah (MMQ), Ijarah, Mudharabah, Murabahah, and Isthisna by state-owned companies then offer the Sukuk to the company pension fund. The methodology in this research uses a system thinking approach with secondary data collection techniques obtained from supporting literature. The result of this research is that the NBFI industry in Indonesia is very important role for the development of infrastructure with the media of pension fund where the instrument is the Sukuk by using musyarakah and Musyarakah Muqtanaqishah (MMQ).
\end{abstract}

\section{Keywords : Sukuk, Musharakah Muqtanaqishah (MMQ), Pension Funds Company, Infrastructure}

\section{PENDAHULUAN}

\section{Latar Belakang}

Fenomena peran Industri Keuangan Non Bank (IKNB) merupakan bagian terpenting dalam peningkatan dan pengembangan peluang ekspansi usaha melalui pengembangan pembiayaan sektor infrastruktur. Realita yang terjadi menggambarkan bahwa pembangunan infrastruktur di Indonesia masih rendah karena suatu infrastruktur yang baik adalah apabila tersedianya infrastruktur yang berkelanjutan. Kondisi pembangunan infrastruktur Indonesia saat ini mengalami berbagai permasalahan diantaranya adalah ketidakjelasan sumber pembiayaan. Untuk itu diperlukan suatu struktur pembiayaan yang tepat untuk mengatasi permasalahan utama dalam pembangunan infrastruktur yang mempunyai keterbatasan akses dalam investasi dengan jumlah dana yang besar, berjangka panjang (long term), dan instrumen dengan mitigasi risiko yang baik.

Infrastruktur merupakan prioritas nasional hal ini disebutkan dalam Rencana Pembangunan Jangka Panjang Nasional (RPJPN) 2005-2025 sebagai salah satu fokus dari prioritas nasional Indonesia. Hal ini didasarkan pada berbagai alasan meliputi: percepatan pertumbuhan ekonomi tidak akan tercapai tanpa difasilitasi oleh infrastruktur nasional, tanpa adanya infrastruktur masyarakat miskin akan terisolasi dari kegiatan perekonomian. Oleh sebab itu investasi di bidang infrastruktur menjadi prioritas pembangunan Indonesia melalui peningkatan kerjasama pendanaan antara pemerintah dan komunitas bisnis (Regulation of The President of the Republic of Indonesia Number 5 of 2010 : Regarding the National Medium-Term Development Plan (RPJMN) 2010-2012, Book 1 National Priorities. Distributed by Ministry of National Development Planning/ National Development Planing Agency 2010). 


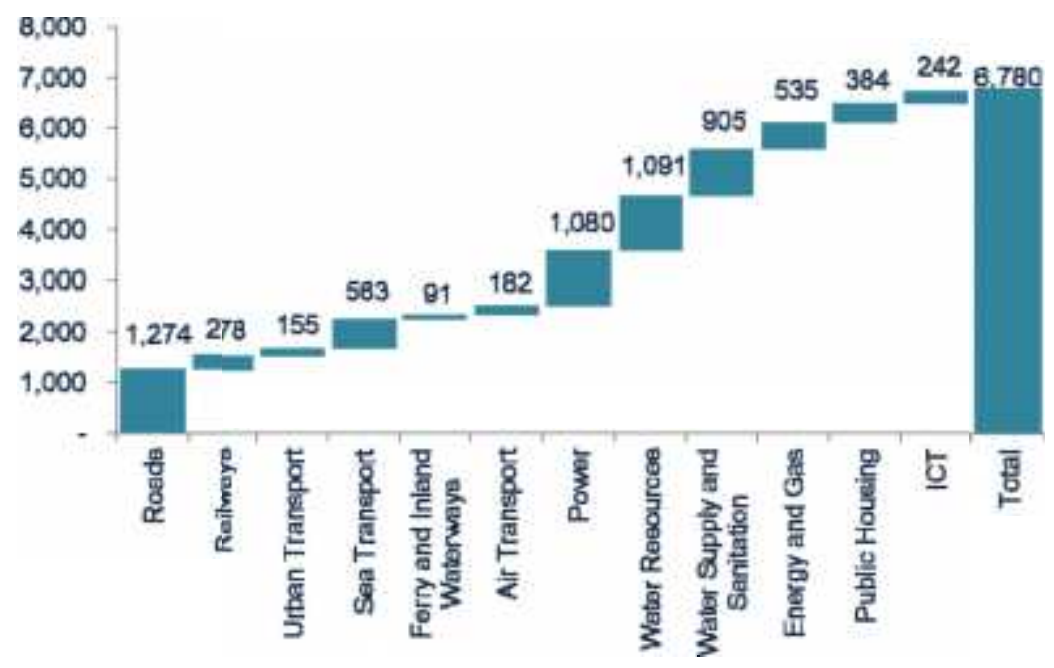

Sumber: Bappenas RPJMN 2015 -2019.

Gambar 1

Anggaran Infrasturktur Tahun 2015-2019

Berdasarkan pencapaian tujuan tersebut, diperlukan adanya strategi dan pergerakan yang tajam seperti peran dari otoritas dalam peningkatan sektor riil seperti peran dari Otoritas Jasa Keuangan (OJK) karena OJK mempunyai peran dalam meningkatkan peran IKNB dimana IKNB berperan dalam pengembangan pembiayaan sektor infrastruktur. Landasan tersebut harus didukung oleh suatu instrumen yang bersinergi dalam jangka panjang untuk pengembangan pembiayaan sektor infrastruktur. Dimana instrumen yang digunakan harus dapat mendukung dan dapat dimitigasi seluruh risikonya sehingga minat investasi untuk sektor infrastruktur di Indonesia meningkat.

Salah satu instrumen keuangan Islam yang tengah berkembang pesat saat ini adalah sukuk. Sukuk pada hakikatnya merupakan sertifikat kepemilikan atas suatu aset (proyek riil) yang dapat digunakan dalam skala besar untuk membiayai pembangunan. Sukuk dipandang sebagai alternatif yang lebih baik daripada berutang karena antara lain mengandung unsur kerja sama investasi, berbagi risiko dan keterlibatan aset (proyek riil) yang juga mendasari penerbitan sukuk (Rifki Ismal, 2009).

Sukuk dari tahun ke tahun mengalami peningkatan penempatan dana oleh perusahaan-perusahaan mutual fund, dana pensiun, dan institusi keuangan lainnya dari negara-negara Eropa dan Asia sebagai bagian dari strategi diversifikasi yang merupakan investor konvensional (Ida Musdafia, 2008). Sehingga saat ini permintaan perkembangan produk syariah juga menjadi kebutuhan bagi industri keuangan syariah. Diantara instrumen keuanga Islam, sukuk telah menjadi daya tarik utama diantara bank-bank, perusahaan dan pelanggan. Sukuk adalah instrumen keuangan beragunan asset yang diterbitkan oleh lembaga keuangan Islam. Saat ini sukuk masih terbatas dan berpotensi untuk dikembangkan baik dari sisi jumlah maupun jenis akad. Sukuk yang diterbitkan Indonesia saat ini baru menggunakan 2 (dua) akad, yaitu akad mudharabahah dan ijarah. 
Sedangkan di negara-negara muslim yang lain akad lebih beragam antara lain akad ijarah, mudharabahah, istishna, musyarakah, murabahah, salam dan hybrid sukuk.

Pertumbuhan sukuk di Indonesia cukup pesat, namun tidak diikuti dengan perkembangan keberagaman jenis akad yang digunakan dalam transaksi penerbitan sukuk. Hingga Tahun 2013, sukuk korporasi yang diterbitkan di Indonesia hanya terdiri dari 2 jenis yakni Sukuk Mudharabah dan Sukuk Ijarah. Sukuk Mudharabah adalah jenis sukuk pertama yang diterbitkan di Indonesia oleh PT. Indosat Tbk pada Tahun 2002 dengan nilai nominal sebesar Rp 175 milyar. Sedangkan jenis sukuk korporasi yang kedua adalah Sukuk Ijarah yang pertama kali diterbitkan oleh PT. Matahari Putra Prima Tbk pada Tahun 2004 dengan nilai nominal Rp 150 milyar. Dari kedua jenis sukuk tersebut, dapat dilihat pada tabel berikut ini bahwa pertumbuhan dan perkembangan Sukuk Mudharabah lebih lambat dibandingkan dengan pertumbuhan dan perkembangan Sukuk Ijarah.

Tabel 1

Emisi Sukuk Mudharabah dan Sukuk Ijarah

Periode Tahun 2002 - 2013

\begin{tabular}{|c|c|c|c|c|}
\hline \multirow{2}{*}{ TAHUN } & \multicolumn{2}{|c|}{ SUKUK MUDHARABAH } & \multicolumn{2}{|c|}{ SUKUK IJARAH } \\
2002 & Lembar & Rp. (miliar) & Lembar & Rp. (miliar) \\
2003 & 1 & 175,0 & - & - \\
2004 & 5 & 565,0 & - & - \\
2005 & 1 & 75,0 & 6 & 579,0 \\
2006 & - & - & 3 & 585,4 \\
2007 & 1 & 125,0 & 1 & 200,0 \\
2008 & - & - & 3 & 900,0 \\
2009 & 1 & 314,0 & 5 & $1.020,0$ \\
2010 & - & - & 14 & $1.980,0$ \\
2011 & 1 & 100,0 & 5 & 997,0 \\
2012 & 1 & 100,0 & - & - \\
2013 & 3 & $1.175,0$ & 3 & 700,0 \\
Total & 5 & $1.204,0$ & 5 & $1.000,0$ \\
\hline
\end{tabular}

Sumber : OJK

Sukuk Ijarah lebih mendominasi penerbitan sukuk di Indonesia sebesar 66,4 \% dari total jumlah sukuk yang diterbitkan di Pasar Modal Indonesia, sedangkan Sukuk Mudharabah hanya sebesar 33,6 \%. Hal ini menunjukkan bahwa Sukuk Ijarah lebih diminati oleh para investor Pasar Modal Indonesia dibandingkan dengan Sukuk Mudharabah.

Alasan sukuk merupakan sebuah instrumen yang baik bagi pengembangan pembiayaan sektor infrastruktur yaitu karena dengan penerbitan sukuk oleh perusahaan BUMN maka akan menarik minat pasar seperti perusahaan dana pensiun yang akan lebih melihat bahwa sukuk dengan fix return yang diterbitkan BUMN dengan pertimbangan akan lebih memberikan keamanan dalam jangka panjang karena dapat mitigasi risiko. 
Apabila bukan melalui sukuk maka lebih sulit dalam hal mitigasi risikonya. Secara otomatis perusahaan dana pensiun akan lebih berminat berinvestasi dengan membeli sukuk yang diterbitkan oleh perusahaan BUMN tersebut.

Dalam penelitian ini akan menawarkan model dalam hal pengembangan pengembangan infrastruktur di Indonesia melalui penerbitan Sukuk yang disesuaikan berdasarkan tujuan penggunaan dan jenis infrastrukturnya, yaitu dengan akad Musyarakah Muqtanaqishah (MMQ), Ijarah, Mudharabah, Murabahah, dan Isthisna oleh perusahaan BUMN kemudian menawarkan Sukuk tersebut kepada perusahaan dana pensiun. Setelah perusahaan dana pensiun memiliki Sukuk tersebut maka perusahaan dana pensiun akan mendapatkan imbal hasil atau nagi hasil atau sewa atau margin berdasarkan kesepakatan bersama, dimana pembayaran tersebut diperoleh perusahaan BUMN dari hasil pemanfaatan infrastruktur berdasarkan rate yang diproyeksikan.

Dengan demikian apabila terdapat alternatif-alternatif akad dari Sukuk yang dapat diaplikasikan dengan menarik pasar investor maka akan mendorong pertumbuhan dari perusahaan pembiayaan infrastruktur berbasis syariah juga, karena apabila dilihat dari overview perusahaan pembiayaan infrastruktur syariah yaitu seperti tabel 1 dibawah ini:

Tabel 2

Perusahaan Pembiayaan Infrastruktur Syariah

\begin{tabular}{|c|c|c|c|c|}
\hline No & Tahun & $\begin{array}{c}\text { Jumlah } \\
\text { Perusahaan }\end{array}$ & $\begin{array}{c}\text { Aset } \\
\text { (Miliar Rp) }\end{array}$ & $\begin{array}{c}\text { Kewajiban } \\
\text { (Miliar Rp) }\end{array}$ \\
\hline $\mathbf{1}$ & Jan-16 & 0 & 0 & 0 \\
\hline $\mathbf{2}$ & Feb-16 & 0 & 0 & 0 \\
\hline $\mathbf{3}$ & Mar-16 & 0 & 0 & 0 \\
\hline $\mathbf{4}$ & Apr-16 & 0 & 0 & 0 \\
\hline $\mathbf{5}$ & Mei-16 & 0 & 0 & 0 \\
\hline $\mathbf{6}$ & Jun-16 & 0 & 0 & 0 \\
\hline $\mathbf{7}$ & Jul-16 & 1 & 101 & 100 \\
\hline $\mathbf{8}$ & Agu-16 & 0 & 0 & 0 \\
\hline $\mathbf{9}$ & Sep-16 & 1 & 103 & 100 \\
\hline $\mathbf{1 0}$ & Okt-16 & 1 & 103 & 100 \\
\hline $\mathbf{1 1}$ & Nov-16 & 1 & 104 & 100 \\
\hline $\mathbf{1 2}$ & Des-16 & 1 & 105 & 100 \\
\hline $\mathbf{1 3}$ & Jan-17 & 1 & 105 & 100 \\
\hline $\mathbf{1 4}$ & Feb-17 & 1 & 107 & 101 \\
\hline $\mathbf{1 5}$ & Mar-17 & 1 & 108 & 100 \\
\hline
\end{tabular}




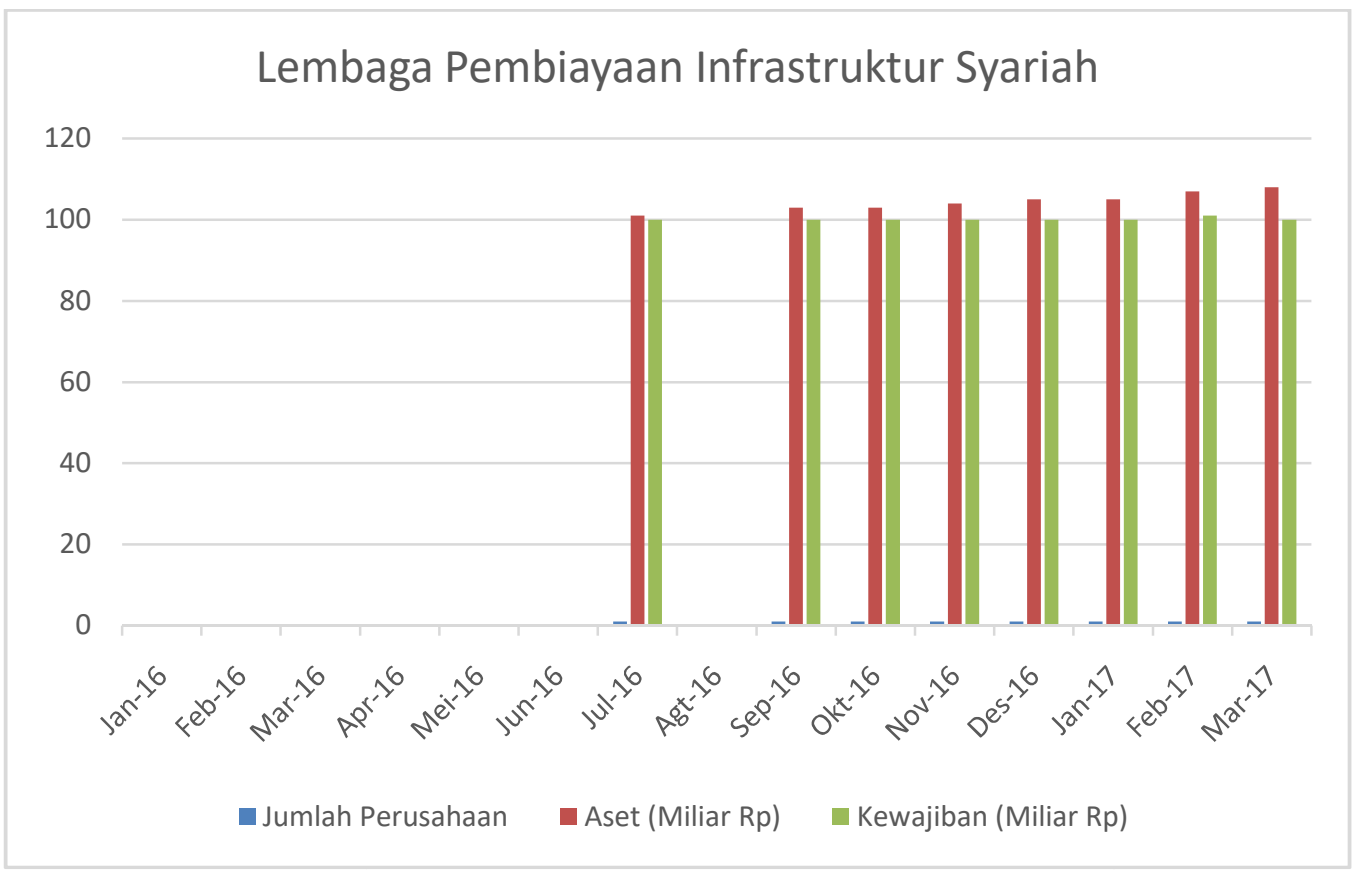

Sumber: Ojk.go.id

\section{Gambar 2}

Overview perusahaan pembiayaan infrastruktur syariah

Berdasarkan tabel dan gambar di atas menggambarkan bahwa begitu kurangnya keberadaan lembaga pembiayaan infrastruktur syariah karena masih terdapat 1 lembaga dan diperlukan dukungan baik materi maupun immateri terhadap keberadaan lembaga tersebut. Apabila lembaga tersebut juga mendukung maka akan diikuti oleh peningkatan pembiayaan infrastruktur berbasis syariah.

Hal tersebut bersinergi dengan tujuan dan fungsi OJK dalam hal mendorong dan memperkuat IKNB dengan peran dana pensiun untuk pengembangan pembiayaan sektor infrastruktur dimana tata kelola dan manajemen risikonya lebih dapat ditindaklanjuti. Sehingga OJK dapat mendorong penempatan dana pensiun kepada struktur infrastruktur, dimana realitas yang berjalan selama ini bahwa dana pensiun menempatkan dananya dalam bentuk deposito, ketika dengan instrumen sukuk maka akan lebih berjangka panjang daripada deposito.

Dalam rangka memberikan solusi atas permasalahan pengembangan pembiayaan sektor infrastruktur maka perlu adanya perluasan alternatif pendanaan bagi investor terhadap produk syariah di pasar. Karenanya Peneliti melakukan pengkajian terkait kemungkinan penerapan dalam stuktur penerbitan sukuk di Indonesia sebagai instrumen yang baik dalam pengembangan pembiayaan sektor infrasturuktur.

Ide penelitian ini didasari oleh menariknya produk Sukuk dengan akad MMQ karena perlu diaplikasikan di Indonesia sebagai pengembangan pembiayaan infrastruktur. Hal ini sejalan dengan fungsi OJK dalam hal menumbuhkan peran dari industri keuangan syariah dalam hal ini yaitu lembaga dana pensiun yang berperan aktif dalam investasi Sukuk ini. 


\section{Rumusan Masalah}

Berdasarkan landasan pemikiran yang telah dijelaskan maka dalam penelitian ini yang menjadi rumusan masalahnya adalah "Bagaimana model yang tepat dalam pengembangan pembiayaan infrastruktur menggunakan instrumen Sukuk yang diterbitkan oleh perusahaan BUMN kemudian Sukuk tersebut dimiliki oleh perusahaan dana pensiun"?

\section{Tujuan Penelitian}

Penelitian ini bertujuan untuk mengetahui dan memahami model yang tepat dalam rangka pengembangan pembiayaan infrastruktur di Indonesia sehingga dapat diketahui penerapannya dalam sektor infrastruktur dengan menggunakan instrumen Sukuk yang diterbitkan oleh perusahaan BUMN, dimana Sukuk tersebut akan menggunakan beberapa pilihan alternatif akad yang digunakan. Seperti akad ijarah, mudharabah, musyarakah muqtanaqishah, dan isthisna.

\section{METODE}

\section{Jenis dan Desain Penelitian}

Jenis penelitian ini menggunakan Pendekatan Berpikir Sistem (Systetm Thinking Approach), yakni pendekatan organisatoris yang menggunakan ciri-ciri sistem sebagai titik tolak analisis. Pendekatan Berpikir Sistem memberikan penyelesaian masalah yang kompleks dengan metode dan alat yang mampu mengidentifikasi, menganalisis, mensimulasi dan mendisain sistem dengan komponen-komponen sistem yang saling terkait, yang diformulasikan secara lintas disiplin dan komplementer untuk mencapai tujuan yang sudah ditetapkan (Eriyatno, 2003). Sedangkan desain penelitian ini adalah Desain Eksplorasi (Exploratory Design) yakni desain penelitian yang dilakukan ketika tidak ada atau masih sedikitnya kajian penelitian yang dilakukan atas suatu masalah. Desain ini menggunakan analisis kualitatif dan didukung oleh analisis kuantitatif. Kedua analisis tersebut dapat digunakan secara bersamaan karena saling melengkapi. (Stainback (1988) dalam Sugiyono (2010).

\section{Teknik Pengumpulan Data}

Data penelitian adalah data sekunder yang diperoleh dari data literatur yang mendukung dan diperoleh dari website ojk. Teknik Pemodelan dilakukan guna menghasilkan suatu formulasi struktur model yang menyerupai sifat-sifat dan perilaku sistem dunia nyata yang kompleks, tetapi dalam bentuk (pola) yang sederhana. Melalui penyederhanaan sistem dunia nyata ke dalam suatu struktur model, maka tingkah-laku elemen-elemen yang menyusun sistem dan interaksi antara satu elemen dengan elemen yang lain di dalam sistem dapat dipelajari dan dianalisis. Teknik Simulasi dilakukan untuk melihat kesesuaian perilaku keluaran model dengan data hitoris dan untuk mempelajari konsekuensi yang dihasilkan oleh perilaku dinamis dari suatu sistem. Simulasi terhadap uji statistik parameter adalah untuk mengevaluasi kualitas dan validitasnya. Hasil simulasi akan memperlihatkan apakah model sistem tersebut merupakan perwakilan yang sahih (valid) dari realitas yang dikaji dan dapat menghasilkan kesimpulan yang meyakinkan. Sedangkan simulasi terhadap skenario-skenario kebijakan dimaksudkan untuk analisis sensitivitas guna mendapatkan gambaran keputusan kebijakan yang terbaik. 


\section{HASIL DAN PEMBAHASAN}

\section{Sukuk}

Sukuk merupakan suatu surat berharga jangka panjang berdasarkan prinsip syariah yang dikeluarkan emiten kepada pemegang sukuk yang mewajibkan emiten untuk membayar pendapatan kepada pemegang sukuk berupa bagi hasil/margin/fee serta membayar kembali dana sukuk pada saat jatuh tempo (Nurul huda dan Mustafa Edwin nasution, 2009).

\section{Jenis-jenis Sukuk dan Akad}

\section{Sukuk Mudharabah}

Sukuk mudharabah adalah kerja sama dengan skema bagi hasil pendapatan atau keuntungan antara pemilik modal dengan pengelola modal. Beberapa alasan yang mendasari pemilihan struktur mudharabah ini, diantaranya:

a. Bentuk padanan yang paling sesuai untuk investasi dalam jumlah besar dan jangka yang relatif panjang.

b. Dapat digunakan untuk padanan umum seperti pendanaan modal kerja ataupun pendanaan capital expenditure.

c. Mudharabah merupakan percampuran keja sama antara modal dan jasa (kegiatan usaha) sehingga membuat strukturnya memungkinkan untuk tidak memerlukan jaminan atas asset yang spesifik. Hal ini berbeda dengan struktur yang menggunakan dasar akad jual beli yang mensyaratkan jaminan atas asset yang didanai (Nurul Huda dan Mohamad Heykal, 2013).

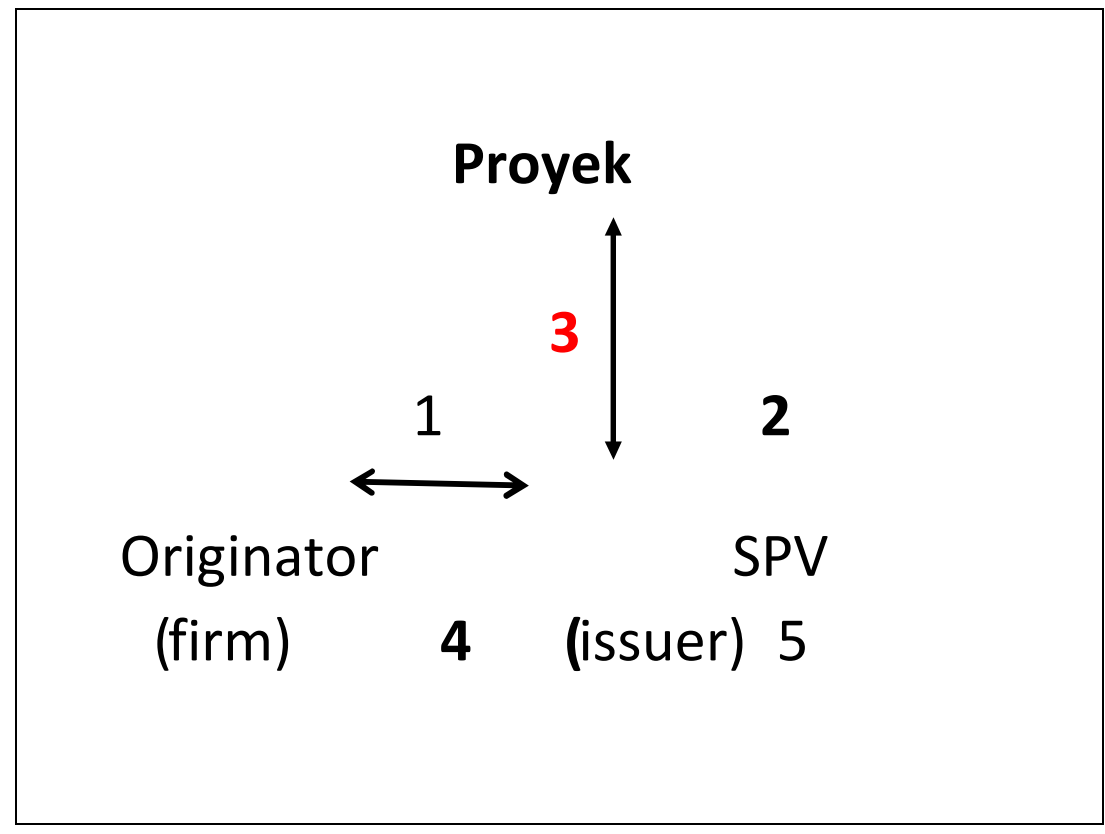

Gambar 3

Mekanisme Pelaksanaan sukuk 
Published Desember 2017

FERONOMIKAWAN : Jurnal Ilmu Ekonomi dan Studi Pembangunan

ISSN : 1693-7600 (Print), ISSN : 2598-0157 (Online), http://furnal.umsu.ac.ld//index.php/ekawan

Gambar di atas adalah skema pelaksanaan sukuk mudharabah adalah sebagai berikut : (1) Originator membuat kontrak sukuk mudharabah dengan SPV, (2) lalu SPV menerbitkan - menawarkan - menyerahkan sertifikat kepada investor, (3) kemudian originator mengerjakan obyek usaha atau proyek dengan pengawasan SPV sebagai wakil investor, (4) setelah itu originator menyerahkan bagi hasil kepada investor melalui SPV, (5) pada akhir masa kontrak originator mengembalikan modal investor dengan cara membeli sesuai harga pasar wajar atau sesuai nilai asset riil atau dilelang kepada umum (Alimin, 2010).

\section{Sukuk ijarah}

Ijarah adalah akad pemindahan hak guna atas barang dan jasa, tanpa diikuti dengan pemindahan kepemilikan barang atas jasa. Sukuk ijarah diterbitkan berdasarkan akad ijarah, diklasifikasikan menjadi sukuk kepemilikan asset berwujud yang disewakan, sukuk kepemilikan manfaat, sukuk kepemilikan jasa. Sukuk kepemilikan asset berwujud yang disewakan, diterbitkan oleh pemilik asset yang disewakan atau yang akan disewakan dengan tujuan untuk menjual asset demi memperoleh dana, sehingga pemegang sukuk menjadi pemilik asset. Sedangkan tujuan penerbitan sukuk kepemilikan manfaat, yaitu menyewakan asset / manfaat asset demi uang sewa, pemegang sukuk menjadi pemilik manfaat dari asset. Penerbitan sukuk kepemilikan jasa bertujuan menyediakan jasa melalui penyedia jasa dan mendapatkan fee, sehingga pemegang sukuk menjadi pemilik jasa.

Penerbitan sukuk iijarah dimulai dari suatu akad jual beli asset (misalnya gedung dan tanah) oleh pemerintah atau perusahaan kepada suatu perusahaan yang ditunjuk, misalnya PT X, untuk suatu jangka waktu tertentu dengan janji membeli kembali setelah jangka waktu tersebut berakhir. Dalam hal ini, bank syariah adalah pemilik asset yang menjualnya kepada PT X sebagai SPV, untuk jangka waktu tertentu dengan janji membeli kembali setelah jangka waktu tersebut berakhir. Akad jual beli ini pada saat bersamaan diikuti dengan akad penyewaan kembali asset tersebut oleh PT X kepada bank syariah selama jangka waktu tersebut. Dengan demikian, akad ini tidak mengubah pemanfaatan terhadap asset tersebut. Dalam istilah keuangan, transaksi seperti ini dikenal dengan backto-back-lease, dan untuk itu PT X diperlukan sebagai SPV, yaitu perusahaan yang khusus didirikan dalam penerbitan sukuk ini.

Berdasarkan deskripsi fatwa AAOIFI dari segi obyek akad, terdapat tiga jenis sukuk ijarah. Pertama, sukuk ijarah Milkiyah al-A'yan al-Mu'jarah atau certificates of ownership in leased assets. Sukuk ijarahMilkiyah al-A'yan al-Mu'jarah yaitu sukuk ijarah yang melambangkan kepemilikan atas aset yang bertujuan untuk disewakan (investor adalah pemilik atas aset dan tentu saja berikut manfaatnya). Contohnya : Investor membeli mesin pabrik kemudian disewakan kepada pemesan. 
Published Desember 2017

EKONOMIKAWAN : Jurnal Ilmu Ekonomi dan Studi Pembangunan

ISSN : 1693-7600 (Print), ISSN : 2598-0157 (Online), http://furnal.umsu.ac.ld//index.php/ekawan

Jenis sukuk ijarah kedua adalah Sukuk ijarah Manafi' al-A'yan al-Musta'jarah atau Certificates of ownership of usufructs of existing assets, yaitu sukuk ijarah yang melambangkan kepemilikan atas manfaat dari aset (bukan wujud aset). Contohnya : Investor menyewa pesawat terbang, kemudian disewakan lagi kepada maskapai penerbangan.

Jenis sukuk yang ketiga adalah sukuk ijarahMilkiyah al-A'mal al-Mujarah atau Certificates of ownership of services of a specified supplier. Contoh : jasa cleaning service sebuah rumah sakit selama jangka waktu tertentu, pelayanan perbaikan sistem pendingin ruangan dan lift, perusahaan penerbangan, kapal laut, komputer, penyulingan minyak (Alimin, 2010).

Ketentuan akad ijarah sebagai berikut (Ascarya, 2007) :

a. Objeknya dapat berupa barang (harta fisik yang bergerak, tak bergerak, harta perdagangan) maupun berbentuk jasa.

b. Manfaat dari objek dan nilai manfaat tersebut diketahui dan di sepakati oleh kedua belah pihak, ruang lingkup dan jangka waktu pemakaiannya harus dinyatakan secara spesifik.

c. Penyewa harus membagi hasil manfaat yang diperolehnya dalam bentuk immbalan atau sewa/upah.

d. Pemakai manfaat (penyewa) harus menjaga objek agar manfaat yang diberikan oleh objek tetap terjaga.

e. Pembeli sewa haruslah pemilik mutlak.

Skema pelaksanaan sukuk ijarah Milkiyah al-A'yan al-Mu'jarahadalah sebagai berikut : (1) perusahaan (originator) memerlukan dana tunai, kemudian membuat kontrak sukuk ijarah dengan SPV; (2) kemudian wali amanat sebagai mediator antara originator dengan investor yang disebut Special Purpose Vihicle disingkat SPV menyerahkan sukuk ijarah kepada investor, investor membayar tunai; (3) selanjutnya SPV membeli property (tanah dan bangunan) milik perusahaan untuk disewakan kembali kepada perusahaan selama 5 tahun; (4) selama masa sewa perusahaan membayar uang sewa kepada investor melalui SPV setiap enam bulan sekali; (5) pada saat jatuh tempo perusahaan membeli kembali property (aset ijarah) dari SPV; (6) akhirnya SPV menyerahkan hasil penjualan property (aset ijarah) kepada investor.

\section{Sukuk Musyarakah}

Sukuk musyarakah yaitu sukuk yang diterbitkan berdasarkan perjanjian atau akad musyarakah, yaitu dua pihak atau lebih bekerja sama menggabungkan modal untuk membangun proyek baru, mengembangkan proyek yang telah ada, atau membiayai kegiatan usaha. Keuntungan ataupun kerugian yang timbul ditanggung bersama sesuai dengan jumlah partisipasi modal masing masing pihak.Sukuk musyarakah ini merupakan sertifikat kepemilikan permanen, yang dimiliki oleh sebuah perusahaan ataupun unit bisnis dengan pengawasan dari pihak manajemen (Nurul Huda dan Mohamad Heykal, 2013). 
Published Desember 2017

Find EKONOMIKAWAN : Jurnal Ilmu Ekonomi dan Studi Pembangunan

ISSN : 1693-7600 (Print), ISSN : 2598-0157 (Online), http://furnal.umsu.ac.ld/Index.php/ekawan

Skema pelaksanaan sukuk musyarakah adalah sebagai berikut : (1) perusahaan membuat kontrak atau akad sukuk musyarakah dengan SPV; (2) SPV menerbitkan sukuk kemudian menjual kepada investor, investor membayar tunai, (3) perusahaan dan SPV berkerjasama dalam proyek, SPV mewakili investor melakukan pengawasan dan pengelolaan proyek, (4) perusahaan menyerahkan bagi hasil dan modal pokok secara berangsur (musyarakah mutanaqisah atau diminishing musharakah or participation) kepada investor melalui SPV, (5) pada akhir masa kontrak, perusahaan mengembalikan modal investor dengan cara membeli sesuai harga pasar sesungguhnya atau nilai aset riil atau dilelang kepada umum.

\section{Sukuk Isthisna}

Sukuk Isthisna yaitu sukuk yang diterbitkan berdasarkan perjanjian atau akad isthisna, yaitu para pihak menyepakati jual beli dalam rangka pembiayaan suatu proyek atau barang. Harga, waktu penyerahan, dan spesifikasi barang atau proyek ditentukan terlebih dahulu berdasarkan kesepakatan (Nurul Huda dan Mohamad Heykal, 2013).

\section{Sukuk Sebagai Instrumen Pengembangan Pembiayaan Infrastruktur Di Indonesia}

Karakteristik keuangan Islam yang mensyaratkan adanya underlying asset transakti riil untuk setiap transaksi keuangan akan menarik dana Timur Tengah ke negara-negara yang siap menyediakan underlying asset. Pasca tragedi World Trade Center 11 September 2001 sentimen anti Amerika Serikat semakin meningkat di dunia Islam, investor yang berasal dari negara-negara kaya petro dollar mengalihkan dananya ke Inggris melalui London Metal Exchange, dan menjadikan tembaga dan metal lainnya sebagai underlying asset. Kondisi tersebut disebabkan negara-negara Asia belum mempersiapkan regulasi dan struktur sistem keuangan secara optimal, kecuali Malaysia yang telah mengembangkan sistem keuangan Islam, sehingga dana-dana yang "eksodus" dari Amerika Serikat banyak yang parkir di negeri Jiran ini. Selain itu adanya kesadaran relijius para investor yang berasal dari Timur Tengah yang notabene beragama Islam untuk menginvestasikan dananya dalam jangka panjang melalui instrumen keuangan yang berbasis syariah (Benyamin C. Esty, 2000).

Besarnya minat pasar terhadap sukuk pada kondisi saat ini, menyebabkan sukuk sebagai salah satu sumber penggerak perekonomian negara termasuk Indonesia. Hal ini disebabkan karena instrumen syariah ini memiliki beberapa kelebihan dibandingkan dengan Surat Utang Negara yang berupa obligasi konvesional yang mengacu pada sistem berbasis bunga. Kelebihan surat berharga syariah negara yaitu sukuk tersebut antara lain : Pertama, sukuk menjamin aliran dana yang diterima akan masuk kepada proyek-proyek investasi sektor riil, karena akad-akad dalam keuangan syariah semuanya berbasis pada sektor riil. Berbeda dengan SUN, yang tidak ada jaminan bahwa uang yang masuk akan diinvestasikan untuk sektor riil. Kedua, sukuk dapat menstimulasi pertumbuhan ekonomi secara lebih baik dibandingkan dengan SUN, karena sukuk memberikan peluang besar terhadap pembukaan lapangan kerja baru bagi masyarakat. Dan hal ini bisa memecahkan masalah kemiskinan dan pengangguran yang terjadi saat ini. 
Published Desember 2017

נג EKONOMIKAWAN : Jurnal Ilmu Ekonomi dan Studi Pembangunan

ISSN : 1693-7600 (Print), ISSN : 2598-0157 (Online), http://jurnal.umsu.ac.ld/Index.php/ekawan

Ketiga, beban utang SUN jauh lebih berat dibandingkan dengan beban return sukuk. Dimana dengan menerbitkan SUN pemerintah berkewajiban untuk membayar sejumlah bunga kepada investor yang bersifat variabel tidak konstan. Sementara dalam sukuk, return bagi investor sangat bergantung pada jenis akad yang digunakan, dan return yang dibayarkan akan berlaku tetap karena adanya kejelasan dan tidak berubah meskipun terjadi shock dalam perekonomi suatu negara.

Selain potensi tersebut, maka yang menjadi kendala dalam pengaplikasian pengembangan sukuk ini antara lain: Pertama, Belum banyak masyarakat yang paham tentang keberadaan obligasi syariah, apalagi sistem yang digunakan, Kedua, Pasar keuangan syariah di Indonesia tidak terlalu likuid. Penyebabnya, pangsa pasarnya relatif kecil, yaitu bahkan cenderung kurang dari 5\% dari seluruh sistem keuangan di Indonesia. Ketiga, Masyarakat dalam menyimpan dananya cenderung didasarkan atas pertimbangan pragmatis. Hal ini menjadikan tren tingkat bunga yang cenderung bisa dipastikan di masa yang akan datang, menjadikan investor lebih memilih obligasi konvensional daripada obligasi syariah (sukuk). Keempat, Conventional dominant; pada kondisi financial dual system Instrumen keuangan termasuk sukuk dihadapkan pada persaingan dengan obligasi sehingga timbul tantangan tersendiri untuk dapat lebih meningkatkan trend sukuk. Selain itu, juga mengingat pasar obligasi khususnya memang lebih banyak diserap oleh pasar konvensional. Kelima, Keterbatasan instrumen; saat ini sukuk masih memiliki keterbatasan dalam segi jenis akad maupun jangka waktu (tenor). Sukuk yang telah diaplikasikan baru terdiri dari sukuk dengan skim ijarah dan mudharabah. Keenam, Nilai issuance atau emisi yang rendah, yang tidak sesuai dengan permintaan investor; pada kondisi pasar, sering terjadi ketidakseimbangan antara demand dan supply dimana jumlah supply yang ada tidak mampu memenuhi kebutuhan investor atau dapat dikatakan masih terbatas. Ketujuh, Pasar sekunder yang kurang likuid; kecenderungan investor dengan hold to maturity dan jumlah seri yang diperdagangkan terbatas menyebabkan rendahnya nilai transaksi di pasar sekunder, sehingga likuiditas pasar menurun dan akibatnya investor akan cenderung meminta imbal hasil yang lebih tinggi dari obligasi.

Berdasarkan permasalahan-permasalahan tersebut, pada dasarnya terlihat kurang memiliki dampak secara langsung terhadap tingkat perkembangan sukuk Indonesia. Akan tetapi jika dilihat secara lebih perspektifnya justru permasalahan-permasalahan mengenai kurangnya informasi masyarakat mengenai instrumen keuangan syariah inilah yang merupakan faktor utama dalam perkembangan instrument keuangan syariah di Indonesia. Karena secara prospeknya, instrumen keuangan syariah berupa sukukini kedepannya, memiliki ruang potensi yang cukup besar disebabkan sifatnya yang cukup jauh berbeda terhadap obligasi konvensional.

\section{Analisa Model Sukuk Musyarakah dan Musyarakah Muqtanaqishah (MMQ)}

Pada penelitian ini akan fokus terkait sukuk dengan akad Musyarakah dan memberikan penawaran terhadap akad MMQ. Sukuk dengan konsep musyarakah merupakan sukuk berbasis ekuitas. Tipe sukuk tersebut tidak menggambarkan utang piutang melainkan proyek atau asset investasi khusus. Pada kasus musyarakah penerbit sukuk dapat merupakan mitra ekuitas di dalam ventura yang akan dibentuk, dengan memberikan kontribusi modal berbentuk uang tunai. Dimana konsep musyarakah ini adalah pengaturan kemitraan di antara dua pihak atau lebih untuk mengusahakan suatu kerjasama bisnis, dimana semua pihak berkontribusi modal, dapat berupa uang tunai. 
Published Desember 2017

נג EKONOMIKAWAN : Jurnal Ilmu Ekonomi dan Studi Pembangunan

ISSN : 1693-7600 (Print), ISSN : 2598-0157 (Online), http://furnal.umsu.ac.ld/Index.php/ekawan

Laba yang diperoleh akan didistribusikan berdasarkan suatu rasio pembagian laba yang ditentukan sebelumnya, tetapi kerugian akan ditanggung bersama berdasarkan partisipasi ekuitas.

Didalam transaksi sukuk musyarakah, penerbit dan juga investor boleh berkontribusi modal pada proyek musyarakah. Dalam hal ini penerbit sukuk adalah perusahaan BUMN yang diberikan kewenangan dan investor adalah perusahaan dana pensiun. Dengan skema berikut ini:

1. Perusahaan penerbit Sukuk adalah perusahaan BUMN

2. Perusahaan dana pensiun adaalah sebagai investor

3. Akad yang digunakan adalah akad musyarakah

4. Sukuk digunakan dalam hal pembiayaan pembangunan infrastruktur yaitu pembangunan jalan tol dimana proyek tersebut masing-masing pihak berkontribusi modal yaitu perusahaan BUMN 20\% dan Investor $80 \%$ dengan periode yang ditetapkan

5. Setelah peusahaan BUMN mendapatkan dana dari penempatan sukuk tersebut, maka dimulailah pembangunan jalan tol

6. Selama investasi berjalan maka perusahaan dana pensiun mendapatkan bagi hasil yang telah disepakati rate nya selama periode yang ditetapkan

7. Untuk mekanisme menggunakan akad MMQ, maka penekanannya adalah adanya perpindahan kepemilikan, yaitu setelah jalan tol dibangun dan hasilnya diperoleh maka berdasarkan pembayaran bagi hasil dari jalan tol tersebut sekalian adanya pembayaran kembali dana investasi sukuk tersebut dari pihak perusahaan BUMN sehingga perusahaan BUMN mempunyai hak kepemilikan 100 persen.

Pertimbangan-pertimbangan pasar dan komersial berpengaruh besar pada penerapan sukuk musyarakah ini. Para penerbit sukuk mempertimbangkan ketika menerbitkan sukuk mereka tidak selalu berharap menghimpun ekuitas, dominannya mereka membuat hutang karena mereka ingin menstrukturkan struktur modal yang efisien bagi perusahaan mereka. Dari perspektif para investor, terdapat berbagai investor dengan karakteristik tersendiri. Saat ini sebagian besar sukuk dijual kepada para investor lembaga yang sedang mencari instrumen-instrumen dengan pendapatan tetap. Para investor tersebut belum siap dengan risiko-risiko aset. Selanjutnya apabila pihak regulator tidak proaktif maka perusahaan penerbit dan para investor kemungkinan terbebani biaya-biaya tambahan dalam menerbitkan sukuk.

Pertumbuhan nilai sukuk yang dihasilkan sangat tergantung pada perkembangan industri keuangan syariah di Indonesia. Menurut hitungan rasional, instrumen sukuk lebih menguntungkan daripada obligasi konvensional, seperti nilai return yang lebih menjanjikan, sistem kepemilikannya, dan keamanan investasi yang ditanggung pemerintah. Dari beberapa pengalaman yang ada, masih tersimpan beberapa penyebab yang sangat mungkin menghambat perkembangan sukuk di Indonesia. Umumnya kendala tersebut berkutat pada sosialisasi kepada investor, opportunity cost, aspek likuiditas, hingga faktor regulasi atau perundang-undangan yang mengatur mengenai sukuk di Indonesia. 


\section{KESIMPULAN}

Berdasarkan penerapan model sukuk dengan akad musyarakah dan MMQ, penelitian ini merekomendasikan yaitu:

1. Pengembangan pembiayaan sektor infrastruktur di Indonesia dengan menggunakan instrumen sukuk dimana akan mempunyai variasi dan jatuh tempo yang lebih panjang dibandingkan dengan deposito. Sukuk yang sudah diaplikasikan saat ini di Indonesia adalah akad ijarah dan mudharabah. Sehingga dapat direkomendasikan

2. Industri keuangan non bank di Indonesia perannya sangat mendukung bagi pengembangan sektor infrastruktur karena salah satu industri keuangan non bank yaitu perusahaan dana pensiun, dimana perusahaan dana pensiun mempunyai dana yang dapat diinvestasikan ke sukuk yang diterbitkan oleh perusahaan BUMN. Selain itu apabila yang menerbitkan sukuk tersebut adalah perusahaan BUMN karena kepentingan bagi perusahaan dana pensiun yang juga harus meminimalisir risiko yang ada sehingga perusahaan dana pensiun tersebut dapat lebih tertarik karena berinvestasi jangka panjang dengan kepercayaan yang tinggi.

3. Sukuk yang telah diaplikasikan saat ini yaitu dengan menggunakan akad ijarah dan mudharabah. Diperlukan adanya inovasi terhadap skema sukuk yang dapat diaplikasikan yaitu dengan menggunakan akad musyarakah dan Musyarakah Muqtanaqishah (MMQ). Hal ini sangat diperlukan sebagai penguatan ketertarikan dari investor.

4. Kerjasama antara akademisi untuk mempersiapkan sumber daya manusia yang paham akan produk dan hukum Islam dan kerjasama dengan Dewan Syariah Nasional dalam memperkaya produk berbasis syariah dengan pemerintah sangat penting bagi perkembangan sukuk di Indonesia umumnya dan perkembangan sukuk pada khususnya.

5. Tingkat peluang yang cukup besar atas perkembangan sukuk sebagai instrumen investasi syariah saat ini, tidak pernah luput dari beberapa kendala dan tantangan yang sedang dihadapi, khususnya pada Indonesia. Dimana tingkat perkembangannya masih cukup rendah dibandingkan perkembangan pada pasar instrumen syariah diberbagai negara lainnya. Seperti Malysia, serta beberapa negara Timur Tengah lainnya. Konteks rendahnya perkembangan instrumen keuangan investasi syariah, tidak luput pula, dari adanya kondisi dimana masih kurangnya informasi yang masyarakat terima mengenai produk serta sistem instrumen investasi syariah. Sehingga dalam hal ini, pemerintah memiliki kewajiban yaitu dalam prospek kedepannya mengenai perkembangan instrumen keuangan syariah yaitu pada dasarnya dengan mengoptimalkan pemberian informasi kepada masyarakat. Sehingga instrumen keuangan syariah itu sendiri mampu dan bisa berkembang sesuai dengan pangsa pasarnya.

\section{DAFTAR PUSTAKA}

Regulation of The President of the Republic of Indonesia Number 5 of 2010 : Regarding the National Medium-Term Development Plan (RPJMN) 2010-2012, Book 1 National Priorities. Distributed by Ministry of National Development Planning/ National Development Planing Agency 2010

Dewan Syariah Nasional MUI - Bank Indonesia, 2006, Himpunan Fatwa Dewan Syariah Nasional MUI edisi revisi tahun 2006 jilid 1, Jakarta : CV Gaung Persada. 
Published Desember 2017

EKONOMIKAWAN : Jurnal Ilmu Ekonomi dan Studi Pembangunan

ISSN : 1693-7600 (Print), ISSN : 2598-0157 (Oniline), http://furnal.umsu.ac.ld/Index.php/ekawan

Iggi H.achsien, 2006, Investasi Syariah di Pasar Modal, menggagas konsep dan praktek manajemen portofolio syariah, Jakarta : PT Gramedia Pustaka Utama.

Muhammad Firdaus NH, Sofiniyah Ghufron, Muhammad Aziz Hakim, Mukhtar Alshodiq, 2005, Sistem kerja pasar modal syariah, briefcase book, edukasi professional syariah, Jakarta : Renaisan.

Nurul Huda dan Mustafa Edwin Nasution, Investasi pada pasar modal syariah (Jakarta : Kencana,2008), 136.

Alimin, 2010, Aplikasi pasar sukuk dalam perspektif syariah (studi analisis kesesuaian syariah terhadap aplikasi pasar sukuk domestic dan global), disertasi doctor, Jakarta : Sekolah Pascasarjana UIN Syarif Hidayatullah.

Nazaruddin, Abdul Majid, 2008, Sukuk Memahami \& Membedah Obligasi pada Perusahaan Otoritas Jasa Keuangan, Jakarta: Rajawali Pers.

Benyamin C. Esty, 2000, The Equate Project: An Introduction to Islamic Project Finance. The Journal of Project Finance. Winter.

Nurul huda dan Mustafa Edwin nasution, 2009, Current Issues Lembaga Keuangan Syariah, Jakarta : Kencana.

Nurul Huda dan Mohamad Heykal, 2013, Lembaga Keuangan Islam Tinjauan Teoritis Dan Praktis, Jakarta, PT Fajar Interpratama Mandiri.

Ascarya, 2007, Akad dan Produk Bank syariah, Jakarta : RajaGrafindo Persada.

Sunarsih, 2008. Manfaat dan Kelebihan Surat Utang Negara Syariah (Sukuk) Atas Surat Utang Negara Yang Berupa Obligasi Konvesional Berbasis Bunga. Fakultas Syari'ah, UIN Sunan Kalijaga, Vol.2, No.2 Juni.

Sofyan, Syafri, 2008. Sukuk Sebagai Instrumen Pendanaan Negara. Fakultas Ekonomi, Universitas Trisakti Jakarta. Vol. II, No.2, Desember. 